\title{
Faktor Risiko Status Gizi Kurang Pada Balita Di UPT Puskesmas Desa Lalang
}

\author{
Dian Lestari Maizs $^{1(\mathrm{k})}$, Zuraidah Nasution $^{(2)}$, Rapida Saragih ${ }^{(3)}$ \\ 1. Gizi dan Kespro S2 IImu Kesehatan Masyarakat, Institut Kesehatan Helvetia, Medan, Indonesia \\ 2. Gizi Poltekes, Politeknik Kesehatan, Medan, Indonesia \\ 3. D-1V Kebidanan, Fakultas Farmasi Dan Kesehatan Institut Kesehatan Helvetia, Medan, Indonesia \\ Email Penulis Korespondensi ${ }^{(\mathrm{k})}$, dianlestarimaizs02@gmail.com
}

\begin{abstract}
Abstrak
Berdasarkan Pemantauan Status Gizi (PSG) dari Kementerian Kesehehatan Republik Indonesia, status gizi kurang pada balita menurut Berat Badan (BB)/Umur (U) sebesar $18,4 \%$. Untuk kota Medan tahun 2017 status gizi kurang pada balita sebesar 6,0\%. Penelitian ini bertujuan untuk menganalisa faktor risiko status gizi kurang pada balita di UPT Puskesmas Desa Lalang Tahun 2018. Jenis penelitian ini adalah case control, Sampel penelitian adalah 30 ibu yang memiliki balita yang mengalami gizi kurang (case) dan 30 ibu yang memiliki balita tidak mengalami gizi kurang (control) di UPT Puskesmas Desa Lalang Kota Medan. Data dianalisis dengan melakukan uji analisis Chi-square dan logistic regression. Hasil penelitian menunjukan dari 5 variabel penelitian hanya 3 variabel yang memengaruhi status gizi kurang pada balita di UPT Puskesmas Desa Lalang Kota Medan tahun 2018 yaitu pengetahuan ibu tentang gizi ( $\operatorname{sig} 0,001$ OR 15,776), pendapatan keluarga(sig 0,004 OR 12,382), dan riwayat infeksi (sig 0,014 OR 7,767). Disarankan bagi ibu balita hendaknya lebih memberikan makanan yang bergizi dan cukup energi untuk anaknya, dalam posyandu setiap bulannya untuk memantau pertumbuhan dan perkembangan anak balita dan lebih aktif mencari informasi tentang gizi balita melalui penyuluhan oleh tenaga kesehatan.
\end{abstract}

Kata Kunci : Status Gizi Kurang Pada Balita

\begin{abstract}
Based on Nutritional Status Monitoring (PSG) from the Ministry of The health of the Republic of Indonesia, malnutrition status in children under five according to Body Weight (BB) / Age (U) is $18.4 \%$. For the city of Medan in 2017 the nutritional status of under-fives was $6.0 \%$. This study aims to analyze the risk factors for malnutrition in children under five in the Village Lalang Village Health Unit in 2018. The type of study used case-control. The sample of this study was 30 mothers who had children under five who experienced malnutrition (case) and 30 mothers who had children under five did not experience poor nutrition (control) in Health Centre Unit Office Desa Lalang, Medan. Data were analyzed by conducting Chi-square analysis and logistic regression. The results of the study showed that from 5 research variables only 3 variables affected underweight status in toddlers at the Lalang Village Health Centre Medan in 2018, namely knowledge about nutrition (sig 0.001 OR 15,776), family income (sig 0.004 OR 12,382), and history of infection (sig 0.014 OR 7,767). It is recommended for mothers of children under five to provide more nutritious food and enough energy for their children, in the posyandu every month to monitor the growth and development of children under five and be more active in seeking information about toddlers nutrition through counselling by health workers.
\end{abstract}

Keywords : Poor nutritional status in toddlers

\section{PENDAHULUAN}

Permasalahan Gizi di Indonesia dan

Negara berkembang umumnya didominasi

oleh masalah
Masalah di Indonesia dan di Negara berkembang pada umumnya masih didominasi oleh Kurang Energi Protein (KEP), masalah anemia besi, masalah Gangguan

http://ejournal.urindo.ac.id/index.php/kesehatan

Article History :

Sumbitted 03 Desember 2020, Accepted 30 Desember 2020, Published 31 Desember 2020 
Akibat Kekuranagan Yodium (GAKY), masalah kurang vitamin $A$, dan masalah gizi kurang. Keseluruhan masalah gizi tersebut masih belum menemukan titik terang untuk dapat diatasi secara menyeluruh, namun muncul masalah gizi baru yang disebut gizi lebih (obsesitas) (1).

Balita merupakan kelompok rentan terkait akibat kekurangan gizi atau pun kelebihan gizi yang berdampak pada kondisi pertumbuhan dan perkembangan yang kurang optimal kedepannya, sehingga memerlukan penanganan yang cepat. Riset Kesehatan Dasar (2013) menunjukkan angka pravalensi gizi kurang pada balita $(B B / U<-2 S D)$ dengan gambaran yang fluktuatif dari tahun 2007 sebesar 17,9\% sampai tahun 2010 sebesar 17,9\% dan tahun 2013 kembali pravalensi gizi kurang meningkat sebesar 19,6\%. Kondisi pravalensi gizi buruk memperlihatkan gambaran yang sama dengan gizi kurang yaitu tahun 2007 sebesar 5,4\% dan tahun 2010 sebesar 4,9\%, namun tahun 2013 meningkat dengan pravalensi 5,7\%. Data tersebut menunjukkan bahwa pada periode tahun 2010-2013 gizi kurang dan gizi buruk mengalami kondisi peningkatan jumlah gizi kurang dan gizi buruk (2).

Data Pemantauan Status Gizi (PSG) dari Kementerian Kesehatan Republik Indonesia tahun 2017 memperlihatkan bahwa status gizi kurang pada balita di Indonesia dinilai dari Berat Badan (BB) menurut Umur (U) sebesar 17,8\%. Di Sumatera Utara (Sumut) pada tahun 2017 menunjukkan angka sebesar 18,4\%. Di kota Medan pada tahun 2017 status gizi kurang pada balita berada di persentase $6,0 \%$. (3).

Masalah gizi di Indonesia tidak terlepas dari pangan yang berkaitan dengan penggunaan segala bahan makanan yang dapat digunakan sebagai makanan (4). Makanan merupakan bahan yang memiliki komponen dengan kandungan zar-zat gizi atau unsur-unsur ikatan kimia yang dapat direaksikan oleh tubuh menjadi zat gizi. Ikatan kimia yang ada dalam zat gizi diperlukan oleh tubuh untuk menghasilkan energi, membangun dan memelihara jaringan, serta mengatur proses-proses kehidupan. Hasil dari akibat mengkonsumsi makanan dan zat-zat gizi digolongkan menjadi 3 kelompok yaitu gizi buruk, baik, dan lebih atau dikenal sebagai status gizi perorangan (5).

Gizi kurang berkaitan dengan tidak terpenuhinya komponen zat gizi oleh tubuh, atau keadaan kekurangan yang terus bertumpuk, derajat keseimbangan yang absolut itu bersifat immaternal. Penyebab terjadinya gangguan gizi secara umum yaitu secara secara langsung dan tidak langung. Penyebab masalah gizi yang terjadi secara langsung khususnya gangguan gizi pada bayi dan anak usia di bawah lima tahun (balita) akibat tidak sesuainya jumlah gizi yang mereka peroleh dari makan dengan kebutuhan tubuh mereka (6). 
Pentingnya memenuhi kebutuhan gizi balita merupakan suatu keharusam karena dapat memengaruhi masa depan si buah hati, terutama pada masa usia 5 tahun pertama. Masa umur 5 tahun pertama sangat menentukan tahun demi tahun perkembangannya dan pada masa tersebut tidak dapat dikembailkan seperti semula bila sudah ada gangguan atau kerusakan akibat tidak tercukupinya kebutuhan gizi harian balita (7).

Penelitian yang dilakukan oleh Dedi Alamsyah menjabarkan bahwa adanya sikap atau perilaku ibu merupakan faktor dalam memilih makanan dan bahan makanan yang tidak benar, tersedoanya jumlah makanan yang cukup serta keanekaragaman makanan yang kurang menjadi persoalan terjadinya masalah gizi kurang dan gizi buruk pada balita. Hal tersebut dipengaruhi oleh rendahnya tingkat pengetahuan ibu tentang makanan dan gizinya (8). Lilis Fauziah dalam penelitiannya menyatakan bahwa balita yang pernah menderita penyakit infeksi berisiko 2,250 kali menderita gizi kurang di bandingkan balita yang tidak pernah menderita penyakit infeksi. Untuk itu orang tua harus lebih memperhatikan pemenuhan asupan makanan dan balita serta kesehatannya sebab terpenuhinya zat gizi dapat menjadi penunjang aktivitas sehari-hari mereka, selain itu gizi juga dapat menunjang sistem kekebalan tubuh balita agar tidak gampang sakit sehingga dapat terhindar dari gizi kurang (9).

Pengetahuan memiliki efek terhadap perilaku ibu untuk menunjang agar anaknya tidak mengalami gizi kurang. Penelitian Made Kurnia menjelaskan bahwa pengetahuan ibu memiliki hubungan positif signifikaan dengan status gizi balita usia 6-24 bulan. Hal ini disebabkan ibu yang memiliki pengetahuan yang tinggi seperti pada ASI memiliki kemungkinan balitanya lebih besar untuk tidak memiliki status gizi di garis merah daripada ibu dengan pengetahuan rendah, sikap ibu memiliki hubungan positif signifikan dengan status gizi balita dengan status gizi diatas garis merah lebih besat datipada ibu dengan kategori sikap rendah (10).

Berdasarkan data yang diperoleh dari Puskesmas UPT Desa Lalang Tahun 2017 di dapatkan jumlah gizi kurang pada balita umur 1-5 tahun 20 orang, pada tahun 2018 ada peningkatan menjadi 30 orang. Sedangkan kasus gizi buruk tidak mengalami perubahan dari tahun sebelumnya yaitu terdapat 7 orang pada tahun 2017-2018 (11). Berdasarkan hasil wawancara peneliti dari 6 orang ibu yang mempunyai balita 1-5 tahun dengan status gizi kurang diketahui 2 orang ibu menyatakan anaknya tidak diberikan ASI ekslusif, 2 orang ibu menyatakan anaknya mengalami diare, dan diketahui 2 orang ibu menyatakan anaknya suka jajan sembarangan daripada makan.

Berdasarkan uraian latar belakang di atas, maka perlu dilakukan kajian 
tentang "Faktor-faktor Yang Berhubungan Dengan Gizi Kurang pada Anak Balita di Wilayah Kerja Puskesmas UPT Desa Lalang Tahun 2018".

\section{METODE}

Desain penilitian ini adalah bersifat survei analitik dengan pendekatan study case control, dimana penelitian ini bertujuan untuk mengetahui pengaruh antara variabel independen terhadap dependent yaitu dengan mengetahui apakah variabel yang diteliti memiliki pengaruh terhadap status gizi kurang pada balita di UPT Puskesmas Desa Lalang Kota Medan (12).

Penelitian ini dilaksanakan di UPT Puskesmas Desa Lalang Kota Medan Dengan alasan: Tersedianya responden serta adanya masalah penelitian. Populasi pada penelitian ini sebanyak 60 orang dengan strategi sampling yaitu purposive sampling yang diambil dengan maksud atau tujuan tertentu karena dianggap memiliki informasi yang dibutuhkan peneliti (12). Pengambilan sampel menggunakan 2 kelompok sampel satu terpapar dan satu lagi kelompok pembanding ,masing-masing 30 responden. Instrumen dalam penelitian didapat dari jawaban subyek melalui pengisian kuesioner, data sekunder dari Puskesmas UPT Desa Lalang, meliputi data jumlah pasien khusus yang menderita gizi kurang.

\section{HASIL PENELITIAN}

Karakteristik responden dalam penelitian adalah ibu yang memiliki balita dengan status gizi kurang yaitu kelompok kasus ibu berusia < 20 tahun sebanyak 1 orang (3,3\%), 20-35 tahun sebanyak 24 orang $(80 \%)$ dan $>35$ tahun sebanyak 5 orang $(16,7 \%)$ sementara kelompok kontrol ibu berusia $<20$ tahun sebanyak 1 orang $(3,3 \%)$, 20-35 tahun sebanyak 27 orang (90\%) dan > 35 tahun sebanyak 2 orang $(6,7 \%)$. Untuk Pendidikan yaitu kelompok kasus ibu berpendidikan rendah (SD-SMP/Sederajat) sebanyak 9 orang (30\%), pendidikan menengah (SMA/Sederajat) sebanyak 20 orang $(66,7 \%)$ dan pendidikan tinggi (D1-S3) sebanyak 1 orang $(3,3 \%)$ sementara kelompok kontrol ibu berpendidikan rendah (SDSMP/Sederajat) sebanyak 4 orang (13,3\%), pendidikan menengah (SMA/Sederajat) sebanyak 23 orang $(76,7 \%)$ dan pendidikan tinggi (D1-S3) sebanyak 3 orang (10\%). Adapun karakteristik responden dapat di lihat pada tabel 1.

Tabel 1. Distribusi Frekuensi Karakteristik Responden

\begin{tabular}{clcccc}
\hline \multirow{2}{*}{ No } & \multirow{2}{*}{ Karakteristik Responden } & \multicolumn{2}{c}{ Kasus } & \multicolumn{1}{c}{ Kontrol } \\
\cline { 3 - 6 } & & $\mathbf{f}$ & Persentase (\%) & $\mathbf{f}$ & Persentase (\%) \\
\hline a & Usia Ibu: & & & & \\
1 & $<20$ Tahun & 1 & 3,3 & 1 & 3,3 \\
2 & 20-35 Tahun & 24 & 80,0 & 27 & 90,0 \\
3 & $>35$ Tahun & 5 & 16,7 & 2 & 6,7 \\
\hline
\end{tabular}




\begin{tabular}{|c|c|c|c|c|c|}
\hline & Jumlah & 30 & 100,0 & 30 & 100,0 \\
\hline b & Pendidikan Ibu: & & & & \\
\hline 1 & $\begin{array}{l}\text { Pendidikan Rendah (SD- } \\
\text { SMP/Sederajat) }\end{array}$ & 9 & 30,0 & 4 & 13,3 \\
\hline 2 & $\begin{array}{l}\text { Pendidikan Menengah } \\
\text { (SMA/Sederajat) }\end{array}$ & 20 & 66,7 & 23 & 76,7 \\
\hline \multirow[t]{2}{*}{3} & $\begin{array}{l}\text { Pendidikan Tinggi (D1-DIII,S1- } \\
\text { S3) }\end{array}$ & 1 & 3,3 & 3 & 10,0 \\
\hline & Jumlah & 30 & 100,0 & 30 & 100,0 \\
\hline
\end{tabular}

Secara analisis univariat menunjukkan bahwa pengetahuan ibu tentang gizi pada kelompok kasus adalah kurang sebanyak 25 orang $(83,3 \%)$ dan baik sebanyak 5 orang $(19,7 \%)$ sementara pada kelompok kontrol kurang sebanyak 7 orang $(23,3 \%)$ dan baik sebanyak 23 orang (76,7\%). Pendapatan keluarga pada kelompok kasus adalah rendah $<$ RP.2.132.188,68 sebanyak 25 orang (83,3\%) dan tinggi $\geq$ RP.2.132.188,68 sebanyak 5 orang $(16,7 \%)$ sementara pada kelompok kontrol adalah rendah $<$ RP.2.132.188,68 sebanyak 10 orang (33,3\%) dan tinggi $\geq R P .2 \cdot 132.188,68$ sebanyak 20 orang $(66,7 \%)$. Jumlah anak pada kelompok kasus adalah banyak sebanyak 21 orang $(70 \%)$ dan sedikit sebanyak 9 orang
(30\%) sementara pada kelompok kontrol adalah banyak sebanyak 12 orang (40\%) dan sedikit sebanyak 18 orang (60\%). Pemberian ASI Eksklusif pada kelompok kasus adalah tidak diberi sebanyak 24 orang $(80 \%)$ dan diberi sebanyak 6 orang (20\%) sementara pada kelompok kontrol adalah tidak diberi sebanyak 13 orang $(43,3 \%)$ dan diberi sebanyak 17 orang $(56,7 \%)$. Riwayat infeksi pada kelompok kasus adalah ya sebanyak 26 orang $(86,7 \%)$ dan tidak sebanyak 4 orang $(13,3 \%)$ sementara pada kelompok kontrol adalah ya sebanyak 8 orang $(26,7 \%)$ dan tidak sebanyak 22 orang $(73,3 \%)$. Adapun distribusi frekuensi variabel penelitian dapat dilihat pada tabel 2 .

Tabel 2. Distribusi Frekuensi Variabel Penelitian

\begin{tabular}{|c|c|c|c|c|c|c|}
\hline \multirow[b]{2}{*}{ No } & \multirow{2}{*}{\multicolumn{2}{|c|}{ Variabel }} & \multicolumn{2}{|c|}{ Kasus } & \multicolumn{2}{|c|}{ Kontrol } \\
\hline & & & $\begin{array}{l}\text { Frekuensi } \\
\text { (f) }\end{array}$ & $\begin{array}{l}\text { Persentase } \\
\text { (\%) }\end{array}$ & $\begin{array}{l}\text { Frekuensi } \\
\text { (f) }\end{array}$ & $\begin{array}{c}\text { Persentase } \\
\text { (\%) }\end{array}$ \\
\hline \multirow[t]{2}{*}{1} & Pengetahuan & Kurang & 25 & 83,3 & 7 & 23,3 \\
\hline & Ibu tentang Gizi & Baik & 5 & 16,7 & 23 & 76,7 \\
\hline \multirow[t]{2}{*}{2} & $\begin{array}{l}\text { Pendapatan } \\
\text { Keluarga }\end{array}$ & $\begin{array}{l}\text { Rendah } \\
<\text { RP.2.132.188,68 }\end{array}$ & 25 & 83,3 & 10 & 33,3 \\
\hline & & $\begin{array}{l}\text { Tinggi } \\
\geq R P .2 \cdot 132 \cdot 188,68\end{array}$ & 5 & 16,7 & 20 & 66,7 \\
\hline \multirow[t]{2}{*}{3} & Jumlah Anak & Banyak & 21 & 70,0 & 12 & 40,0 \\
\hline & & Sedikit & 9 & 30,0 & 18 & 60,0 \\
\hline 4 & $\begin{array}{l}\text { Riwayat } \\
\text { Pemberian ASI } \\
\text { Eksklusif }\end{array}$ & Tidak diberi & 24 & 80,0 & 13 & 43,3 \\
\hline
\end{tabular}


Jurnal Bidang IImu Kesehatan

\begin{tabular}{llcccc} 
& Diberi & 6 & 20,0 & 17 & 56,7 \\
\multirow{3}{*}{ Riwayat Infeksi } & Ya & 26 & 86,7 & 8 & 26,7 \\
& Tidak & 4 & 13,3 & 22 & 73,3 \\
\hline
\end{tabular}

Secara analisis bivariat menunjukkan

bahwa berdasarkan uji chi-square di dapatkan ada risiko pengetahuan ibu tentang gizi, pendapatan keluarga, jumlah anak,
Riwayat pemberian ASI eksklusif dan Riwayat infeksi dengan status gizi kurang pada balita. Ada pun hasil uji chi-square dapat dilihat pada tabel 3.

Tabel 3. Hasil Uji Chi-Square

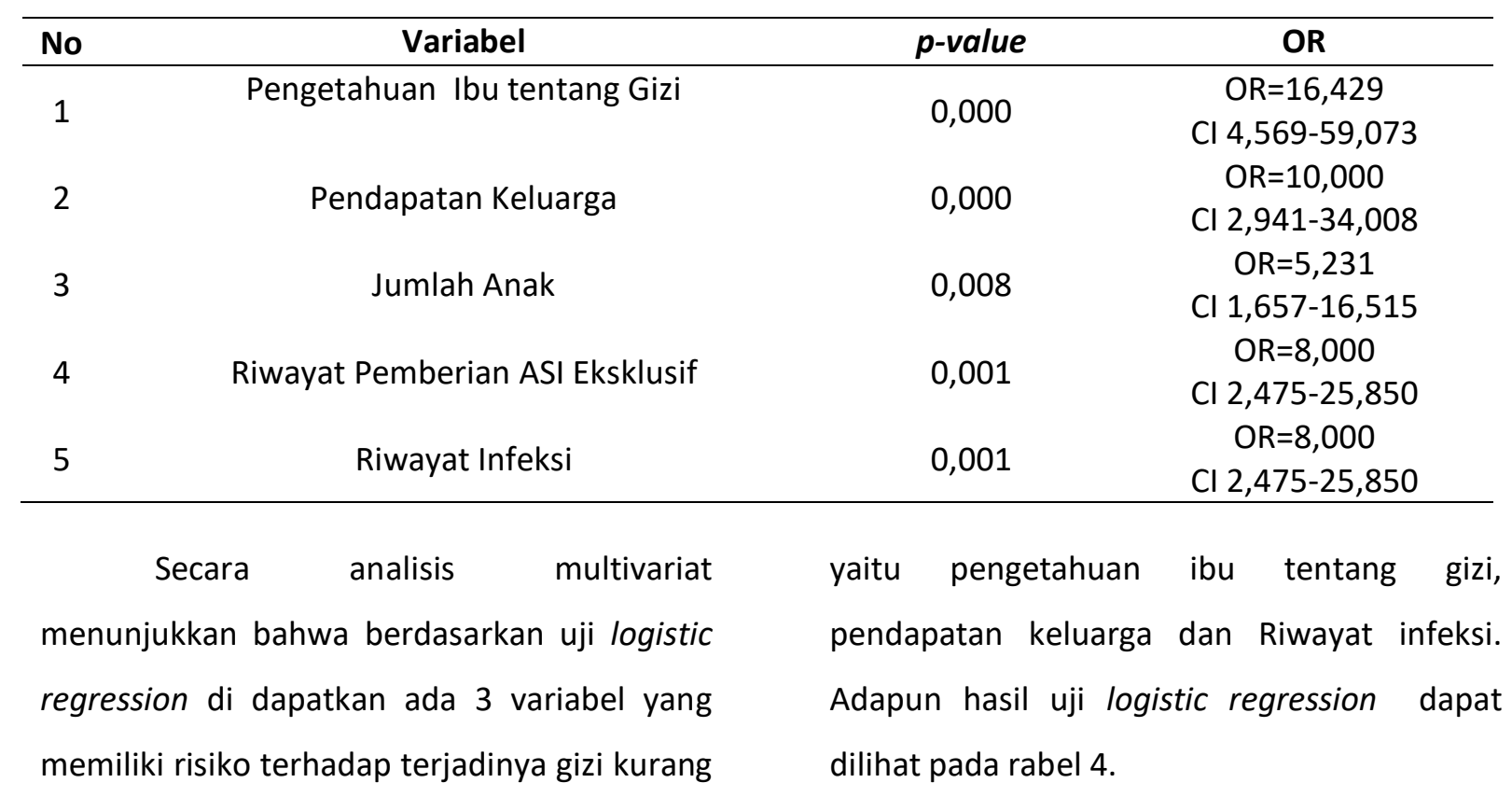

Tabel 4. Hasil Uji Logistic Regression

\begin{tabular}{|c|c|c|c|c|c|c|c|}
\hline \multirow{2}{*}{ No } & \multirow{2}{*}{ Variabel } & \multirow{2}{*}{ B } & \multirow{2}{*}{ Wald } & \multirow{2}{*}{ Sig. } & \multirow{2}{*}{$\operatorname{Exp}(B)$} & \multicolumn{2}{|c|}{ 95\% C.I.for EXP(B) } \\
\hline & & & & & & Lower & Upper \\
\hline 1 & $\begin{array}{l}\text { Pengetahuan Ibu } \\
\text { tentang Gizi }\end{array}$ & 2,758 & 10,819 & 0,001 & 15,776 & 3,049 & 81,633 \\
\hline 2 & Pendapatan Keluarga & 2,516 & 8,257 & 0,004 & 12,382 & 2,225 & 68,888 \\
\hline 3 & Riwayat Infeksi & 2,050 & 5,988 & 0,014 & 7,767 & 1,504 & 40,113 \\
\hline
\end{tabular}

PEMBAHASAN

Faktor Risiko Pengetahuan Ibu tentang Gizi dengan Gizi Kurang pada Balita di UPT

\section{Puskesmas Desa Lalang Kota Medan Tahun} 2018.

Berdasarkan hasil penelitian didapatkan didapatkan dari 60 ibu di 
dapatkan mayoritas pengetahuan ibu tentang gizi kurang pada kasus sebanyak 25 orang $(83,3 \%)$ dan pada kontrol sebanyak 7 orang $(23,3 \%)$. Karena nilai OR $>1$ dengan nilai sebesar $\quad 16,429$ (Cl 4,569-59,073) menunjukkan bahwa pengetahuan ibu tentang gizi kurang mempunyai risiko 16,429 kali lebih besar memiliki balita dengan status gizi kurang daripada pengetahuan ibu tentang gizi baik. Hasil penelitian ini sejalan dengan penelitian yang dilakukan oleh Made Kurnia Widiastuti Giri, "Hubungan Pengetahuan dan Sikap Ibu Tentang Pemberian ASI EKsklusif Dengan Status Gizi Balita Usia 6-24 Bulan di Kelurahan Kampung Kajanan Kec Buleleng". Menyimpulkan bahwa ada hubungan pengetahuan $(p=0,011 O R=25,196 ; C l 95 \%=$ 2, 087 hingga 304, 158) dengan status gizi balita usia 6-24 bulan (10). Penelitian ini sejalan dengan Terati Terati, Nurul Salasa Nilawati dan Riskikah Dwi Fatonah, "FaktorFaktor Yang Berhubungan Dengan Status Gizi Balita Usia 06-60 Bulan Di Kelurahan Kuto Batu Kecamatan Ilir Timur li Kota Palembang Th 2011". Menyimpulkan bahwa ada hubungan antara tingkat pengetahuan ibu tentang gizi dan kesehatan, di mana p_value < 0,05 (13). Pengetahuan merupakan hasil "tahu" dan terjadi setelah mengadakan penginderaan terhadap suatu objek tertentu. Pada waktu penginderaan sampai menghasilkan pengetahuan dipengaruhi oleh intensitas perhatian pwrsepsi terhadap objek, sehingga pengaruh dari apa yang ia dengar, lihat dan rasakan memengaruhi tingkatan pengetahuannya (14). Menurut asumsi peneliti pengetahuan ibu tentang gizi merupakan segala sesuatu yang ibu ketahui mengenai gizi, baik jenis pangannya, proses pengolahannya dan kebutuhan gizi yang untuk balita sesuai dengan umurnya. Pengetahuan ibu dipengaruhi oleh bagaimana informasi yang diterima ibu baik dari media cetak/elektronik dan lingkungan ibu tinggal, seperti keluarga, teman, bahkan petugas kesehatan itu sendiri untuk memenuhi kebutuhan gizi balitanya. Hasil penelitian menunjukkan mayoritas faktor risiko pengetahuan responden kurang pada kelompok kasus mengalami balita dengan status gizi kurang lebih besar $60 \%$ daripada kelompok kontrol.

\section{Faktor Risiko Pendapatan Keluarga terhadap} Gizi Kurang pada Balita di UPT Puskesmas Desa Lalang Kota Medan Tahun 2018.

Berdasarkan hasil penelitian didapatkan didapatkan dari 60 ibu di dapatkan mayoritas pendapatan keluarga rendah pada kasus sebanyak 25 orang $(41,7 \%)$ dan pada kontrol sebanyak 10 orang $(16,7 \%)$. Karena nilai $O R>1$ dengan nilai sebesar $10,000(\mathrm{Cl} 2,941-34,008)$ menunjukkan bahwa pendapatan rendah mempunyai risiko 10,000 kali lebih besar memiliki balita dengan status gizi kurang daripada pendapatan keluarga tinggi. Hasil penelitian ini sejalan dengan penelitian yang dilakukan oleh Rona Firmana 
Putri, "Faktor-Faktor yang Berhubungan dengan Status Gizi Anak Balita di Wilayah Kerja Puskesmas Nanggalo Padang". Menyimpulkan bahwa ada hubungan pendapatan keluarga $(p=0,013 ; \quad O R=3,058$; $C \mid 95 \%=1,246-7,4)$ dengan status gizi anak balita (15). Penelitian Vonny Persulessy, Abidillah Mursyid, Agus Wijanarka "Tingkat pendapatan dan pola makan berhubungan dengan status gizi balita di Daerah Nelayan Distrik Jayapura Utara Kota Jayapura". Menyimpulkan bahwa Tingkat pendapatan dengan status gizi menunjukkan hubungan yang bermakna dengan nilai $(p=0,000)$ (16). Pendapatan adalah imbalan yang diterima baik berbentuk uang maupun barang, yang dibayarkan perusahaan/kantor/majikan. Imbalan dalam bentuk barang dinilai dengan harga setempat (6). Menurut asumsi peneliti pendapatan berkaitan dengan bagaimana pola konsumsi pangan terkait dengan pemenuhan gizi pada anggota keluarganya, khususnya balitanya, sehingga dapat membeli jenis pangan yang beragam baik secara kualitas dan kuantitas. Untuk memenuhi kebutuhan gizi balita membutuhkan makanan yang bervariasi sehingga balita tidak merasa bosan dengan makanan yang itu-itu saja. Hasil penelitian menunjukkan mayoritas faktor risiko pendapatan rendah keluarga pada kelompok kasus mengalami balita dengan status gizi kurang lebih besar $25 \%$ daripada kelompok kontrol.
Faktor Risiko Jumlah Anak dengan Gizi Kurang pada Balita di UPT Puskesmas Desa Lalang Kota Medan Tahun 2018.

Berdasarkan hasil penelitian didapatkan didapatkan dari 60 ibu di dapatkan mayoritas jumlah anggota keluarga banyak pada kasus sebanyak 21 keluarga $(30,0 \%)$ dan pada kontrol sebanyak 12 keluarga $(20,0 \%)$. Karena nilai $O R>1$ dengan nilai sebesar 3,500 (Cl 1,201-10,196) menunjukkan bahwa jumlah keluarga banyak mempunyai risiko 3,500 kali lebih besar memiliki balita dengan status gizi kurang daripada jumlah anggota keluarga sedikit. Hasil penelitian ini sejalan dengan penelitian yang dilakukan oleh Rona Firmana Putri, "Faktor-Faktor yang Berhubungan dengan Status Gizi Anak Balita di Wilayah Kerja Puskesmas Nanggalo Padang". Menyimpulkan bahwa ada hubungan jumlah anak $(p=0,008)$ dengan status gizi anak balita (15). Penelitian lain Ima Nurapriyanti, Sarwinanti "FaktorFaktor Yang Mempengaruhi Status Gizi Balita Di Posyandu Kunir Putih 13 Wilayah Kerja Puskesmas Umbulharjo I Kota Yogyakarta Tahun 2015". Menyimpulkan ada pengaruh jumlah anggota keluarga dengan status gizi balita $p<0,05$ (17).Program pemerintah melalui program keluarga berencana telah menganjurkan norma keluarga kecil bahagia sejahtera yaitu 2 anak saja dan jarak antara anak satu dengan yang lain adalah 3 tahun, hal ini dimaksudkan agar orang tua dapat memberikan kasih sayang dan perhatian pada 
anaknya, anak mendapatkan kebutuhan yang diperlukan untuk pertumbuhan dan perkembangannya, selain itu secara ekonomi norma keluarga kecil di rasa memberikan dampak secara ekonomi yang jauh menguntungkan, sehingga kesejahteraan keluarga lebih terjamin (18). Menurut asumsi peneliti jumlah anak dalam keluarga sangat menentukan pengeluaran keluarga terkait dengan kemampuan keluarga untuk membeli kebutuhan pangan yang dikondisikan jumlah anggota keluarga. Hasil penelitian menunjukkan mayoritas faktor risiko jumlah anggota keluarga banyak pada kelompok kasus mengalami balita dengan status gizi kurang lebih besar 30,0\% daripada kelompok kontrol.

\section{Faktor Risiko Riwayat Pemberian ASI Ekslusif dengan Gizi Kurang pada Balita di UPT Puskesmas Desa Lalang Kota Medan Tahun 2018.}

Berdasarkan hasil penelitian didapatkan didapatkan dari 60 ibu di dapatkan mayoritas riwayat tidak diberikan ASI eksklusif pada kasus sebanyak 24 balita $(40,0 \%)$ dan pada kontrol sebanyak 13 balita $(21,7 \%)$. Karena nilai $O R>1$ dengan nilai sebesar 5,231 (Cl 1,657-16,515) menunjukkan bahwa riwayat tidak diberikan ASI eksklusif mempunyai risiko 5,231 kali lebih besar memiliki balita dengan status gizi kurang daripada riwayat diberikan ASI eksklusif. $(O R>1)$ Hasil penelitain ini sejalan dengan penelitian yang dilakukan oleh Ima Nurapriyanti, Sarwinanti, "Faktor-Faktor Yang Mempengaruhi Status Gizi Balita Di Posyandu Kunir Putih 13 Wilayah Kerja Puskesmas Umbulharjo I Kota Yogyakarta Tahun 2015". Menyimpulkan bahwa ada ada pengaruh pola asuh, infeksi penyakit, asupan makanan, ketahanan pangan, kesehatan lingkungan, ASI Eksklusif, pendidikan, tingkat pengetahuan, pekerjaan, pendapatan, jumlah anggota keluarga dengan status gizi balita $p<0,05$ dan asupan makan merupakan faktor yang paling dominan mempengaruhi status gizi balita dengan nilai $B=0,313$ dan $p=0,028$ (17). Menurut asumsi peneliti ASI eksklusif merupakan makanan yang secara alami sudah dikondisikan untuk memenuhi kebutuhan bayi sampai umur 0-6 bulan dan dilanjutkan sampai berumur 2 tahun, sebab ASI masih mampu memenuhi kebutuhan bayi berumur 6-12 bulan sebanyak $40 \%$ dan pada setelah bayi berumur 1 tahun maka ASI tetap mampu memenuhi kebutuhan anak sebesar 30\%, sehingga sisanya harus dipenuhi dari pemberian makanan sesuai kebutuhan balita. Dengan kemampuan ASI yang mampu memenuhi kebutuhan balita sebesar 30\% setelah berumur 1 tahun ditambah dengan anak diberikan makanan sesuai dengan tingkatan umurnya maka anak tidak akan mengalami permasalahan gizi. Setidaknya pemenuhan gizi balita diluar ASI tidak begitu banyak sebab ibu tetap melanjutkan ASI. Kandungan ASI salah satunya adalah sebagai 
zat anti infeksi yang baik untuk mencegah anak terjangkit penyakit infeksi berulang sehingga tidak mengganggu tumbuh kembang anak sampai kemasa lanjutnya. Hasil penelitian menunjukkan bahwa mayoritas faktor risiko riwayat tidak diberikan ASI eksklusif pada kelompok kasus mengalami balita dengan status gizi kurang lebih besar $36,7 \%$ daripada kelompok kontrol.

\section{Faktor Risiko Riwayat Infeksi terhadap Gizi} Kurang pada Balita di UPT Puskesmas Desa Lalang Kota Medan Tahun 2018.

Berdasarkan hasil penelitian didapatkan mayoritas dengan riwayat infeksi sebanyak 34 balita $(56,7 \%)$ mengalami status gizi kurang sebanyak 24 balita $(40,0 \%)$ dan status gizi baik sebanyak 10 balita $(16,7 \%)$. Karena nilai $O R>1$ dengan nilai sebesar 8,000 ( $\mathrm{Cl}$ 2,475-25,860) menunjukkan bahwa riwayat infeksi mempunyai risiko 8,000 kali lebih besar mengalami status gizi kurang daripada riwayat tidak infeksi $(O R>1)$. Hasil penelitian ini sejalan dengan penelitian yang dilakukan Lilis Fauziah, "Faktor Resiko Kejadian Gizi Kurang Pada Balita Usia 24-59 Bulan di Kelurahan Taipa Kota Palu". Menyimpulkan bahwa balita yang pernah menderita penyakit infeksi berisiko 2,250 kali menderita gizi kurang dibandingkan balita yang tidak pernah mengalami penyakit infeksi dan tidak bermakna signifikan ( $\mathrm{Cl}$ : 0,8106,252) (9). Sejalan dengan penelitian Hadiana, Suman Yus Me, "Hubungan Status Gizi Terhadap Terjadinya Infeksi Saluran
Pernapasan Akut (ISPA) Pada Balita Di Puskesmas Pajang Surakarta". Menyimpulkan terdapat hubungan yang signifikan antara status gizi terhadap terjadinya infeksi saluran pernapasan akut pada balita, selain itu didapatkan nilai RP (ratio prevalensi) $=27,5$ (Interval kepercayaan 95\% (8,372-90,328) artinya bahwa anak yang mengalami gizi kurang beresiko 27,5 kali untuk mengalami (ISPA) dibanding balita yang mempunyai gizi baik (19). Gangguan defesiensi gizi dan rawan infeksi merupakan suatu pasangan yang erat, maka perlu ditinjau kaitannya satu sama lain. Infeksi bisa berhubungan dengang gangguan gizi melalui beberapa cara, yaitu mempengaruhi nafsu makan, menyebabkan kehilangan bahan makanan. Infeksi akut menyebabkan kurangnya nafsu makan dan toleransi terhadap makanan. Penyakit ini juga menghabiskan sejumlah protein dan dan kalori yang seharusnya dipakai untuk pertumbuhan (6).

Menurut asumsi peneliti infeksi merupakan suatu kondisi masuknya parasit, bakteri bahkan virus kedalam tubuh seseorang, sehingga menyebabkan terjadinya berbagai penyakit. Kondisi tersebut akan mempengaruhi status gizi balita melalui cara parasit memanfaatkan gizi untuk pertumbuhan parasit, sehingga balita membutuhkan asupan gizi 2 kali lipat dari semestinya, parasit atau infeksi akan mempengaruhi penurunan cairan tubuh, seperti diare dan muntah, serta penurunan 
nafsu makan pada balita yang berdampak pada status gizi balita. Hasil penelitian menunjukkan bahwa mayoritas faktor risiko riwayat menderita riwayat infeksi pada kelompok kasus mengalami balita dengan status gizi kurang lebih besar 30\% daripada kelompok kontrol.

\section{SIMPULAN}

Dari hasil penelitian yang telah di lakukan di UPT Puskesmas Desa Lalang Kota Medan tahun 2018 dengan responden sebanyak 60 orang, maka peneliti dapat menarik kesimpulan yaitu:

1. Ada hubungan pengetahuan ibu tentang gizi dengan gizi kurang pada balita di UPT Puskesmas Desa Lalang Kota Medan tahun 2018 dengan nilai $p$-value 0,000 $\mathrm{OR}=16,429 \mathrm{Cl}$ 4,569-59,073

2. Ada hubungan pendapatan keluarga dengan gizi kurang pada balita di UPT Puskesmas Desa Lalang Kota Medan tahun 2018 dengan nilai $p$-value 0,000 $\mathrm{OR}=10,000 \mathrm{Cl} 2,941-34,008$.

3. Ada hubungan jumlah anak dengan gizi kurang pada balita di UPT Puskesmas Desa Lalang Kota Medan tahun 2018 dengan nilai $p$-value $0,038 \mathrm{OR}=3,500 \mathrm{Cl}$ 1,201-10,196 .

4. Ada hubungan riwayat pemberian ASI eksklusif dengan gizi kurang pada balita di UPT Puskesmas Desa Lalang Kota Medan tahun 2018 dengan nilai $p$-value 0,008 OR=5,231 Cl 1,657-16,515
5. Ada hubungan riwayat infeksi dengan gizi kurang pada balita di UPT Puskesmas Desa Lalang Kota Medan tahun 2018 dengan nilai $p$-value $0,001 \quad \mathrm{OR}=8,000 \mathrm{Cl}$ 2,475-25,850.

6. Faktor risiko yang paling dominan dengan gizi kurang pada Balita di UPT Puskesmas Desa Lalang Kota Medan Tahun 2018 adalah riwayat infeksi pada balita dengan nilai sig 0,001 $\operatorname{Exp}(\mathrm{B}) \mathrm{OR} 15,776 \mathrm{Cl} 3,049$ 81,663 .

\section{UCAPAN TERIMAH KASIH}

Terima kasih peneliti ucapkan kepada Kepala Pukesmas beserta ahli gizi dan staff di UPT Puskesmas Desa Lalang Kota Medan yang ikut berpartisipasi dan membantu dalam proses penyelesaian penelitian ini.

\section{DAFTAR PUSTAKA}

Supriasa IDN. Penilaian Status Gizi. Jakarta: EGC; 2016.

Riset Kesehatan Dasar Riskesdas 2013. Jakarta: Badan Penelitian dan Pengembangan Kesehatan Kementerian KesehataN RI; 2013.

Buku Saku Pemantauan Status Gizi (PSG) TAHUN 2017. Jakarta: Direktorat Gizi Masyarakat Direktorat Jenderal Kesehatan Masyarakat Kementerian Kesehatan 2018; 2018.

Marmi. Gizi dalam kesehatan reproduksi. Yogyakarta: pustaka pelajar; 2013. 450 p. 
Pekik I. Pedoman Gizi Lengkap Keluarga dan Olahragawan. Yogyakarta: Andi; 2017. $375 \mathrm{p}$.

Adriani M, Wirjatmadi B. Gizi dan Kesehatan balita. Jakarta: Kencana; 2014.

Mardalena I. Dasar-Dasar IImu Gizi dalam Keperawatan Konsep dan Penerapan Pada Asuhan Keperawatan. Yogyakarta: Pustaka Baru Press; 2017. Alamsyah D, Mexitalia M, Margawati A. Beberapa Faktor Risiko Gizi Kurang dan Gizi Buruk pada Balita 12-59 Bulan. J Vokasi Kesehat. 2015;1(5):131-5.

Fauziah L. Faktor Risiko Kejadian Gizi Kurang pada Balita Usia 24-59 Bulan di Kelurahan Taipa Kota Palu. Prev J Kesehat Masy. 2016;7(2):6.

Giri MKW. Hubungan Pemberian ASI eksklusif dengan Status Gizi Balita Usia 6-24 Bulan di Kampung Kajanan, Buleleng. JST (Jurnal Sains dan Teknol. 2013;2(1).

Hasil Pemantaun Status Gizi Balita di UPTD Puskesmas Desa Lalang Kota Medan. Medan; 2017.

12. Swarjana IK. Metodologi Penelitian Kesehatan. Revisi. Jakarta: Andi Offset; 2015.

Terati T, Nilawati NS, Fatonah RD. FaktorFaktor Yang Berhubungan dengan Status Gizi Balita Usia 06-60 Bulan Di Kelurahan Kuto Batu Kecamatan Ilir Timur li Kota Palembang Th 2011. JPP (Jurnal Kesehat Poltekkes Palembang). 2013;2(12):1-21.
Notoadmojo S. Pendidikan dan Perilaku Kesehatan. Jakarta: Rineka Cipta; 2003. Putri RF, Sulastri D, Lestari Y. Faktor-Faktor yang Berhubungan dengan Status Gizi Anak Balita di Wilayah Kerja Puskesmas Nanggalo Padang. J Kesehat Andalas. 2015;4(1).

Persulessy V, Mursyid A, Wijanarka A. Tingkat Pendapatan dan Pola Makan Berhubungan dengan Status Gizi Balita di Daerah Nelayan Distrik Jayapura Utara Kota Jayapura. J Gizi dan Diet Indones (Indonesian J Nutr Diet. 2016;1(3):143-50.

Nurapriyanti I, Sarwinanti S. Faktor-Faktor yang Mempengaruhi Status Gizi Balita di Posyandu Kunir Putih 13 Wilayah Kerja Puskesmas Umbulharjo I Kota Yogyakarta Tahun 2015. Universitas' Aisyiyah Yogyakarta; 2016.

$$
\begin{array}{cccc}
\text { Peran } & \text { BKKBN di } & \text { Balik } & \text { Gerakan } \\
\text { Penanggulangan Stunting. } & \text { J } & \text { Kel } \\
\text { (Informasi Kependudukan, KB } & \text { dan } \\
\text { Pembang Keluarga). 2018;1. } &
\end{array}
$$

Hadiana SYM. Hubungan Status Gizi terhadap Terjadinya Infeksi Saluran Pernapasan Akut (ISPA) Pada Balita di Puskesmas Pajang Surakarta. Universitas Muhammadiyah Surakarta; 2013. 